\title{
Responses of 11 Fraxinus Cultivars to Ash Yellows Phytoplasma Strains of Differing Aggressiveness
}

\author{
W. A. Sinclair, Department of Plant Pathology, Cornell University, Ithaca, NY 14853; M. L. Gleason, Department \\ of Plant Pathology, Iowa State University, Ames 50011; H. M. Griffiths, Department of Plant Pathology, Cornell \\ University; J. K. Iles, Department of Horticulture, Iowa State University; N. Zriba, D. V. Charlson, and J. C. \\ Batzer, Department of Plant Pathology, Iowa State University; and T. H. Whitlow, Department of Floriculture and \\ Ornamental Horticulture, Cornell University
}

\begin{abstract}
Sinclair, W. A., Gleason, M. L., Griffiths, H. M., Iles, J. K., Zriba, N., Charlson, D. V., Batzer, J. C., and Whitlow, T. H. 2000. Responses of 11 Fraxinus cultivars to ash yellows phytoplasma strains of differing aggressiveness. Plant Dis. 84:725-730.

Five cultivars of Fraxinus americana (white ash) and five of $F$. pennsylvanica (green ash) were graft-inoculated with three strains of ash yellows phytoplasmas at Ames, IA, and with three other strains at Ithaca, NY. A sixth green ash cultivar was tested only in New York. Trees were allowed to grow in field plots for 3 years. Infection was detected via the DAPI (4',6-diamidino2-phenylindole-2 $\mathrm{HCl}$ ) fluorescence test. Incidence of witches'-brooms on infected trees was greater on white ash than green ash and varied significantly among phytoplasma strain treatments at both locations. Volume growth of infected ash, averaged across cultivars over 2 years in Iowa and 3 years in New York, was 49 and 59\%, respectively, as great as that of noninfected trees. Foliar greenness was reduced significantly by infection at both locations, and this reduction was positively correlated with growth reduction. Cultivars at each location varied significantly in growth of noninfected trees and in growth of diseased trees relative to that of noninfected trees (a measure of phytoplasma tolerance), but cultivar means for these variables in Iowa were not significantly correlated with those in New York. Green ash cvs. Bergeson, Dakota Centennial, and Patmore and white ash cv. Autumn Applause were above average in tolerance at both locations. Phytoplasma strains at each location varied significantly in aggressiveness as indicated by host growth suppression.
\end{abstract}

Additional keyword: virulence

The phytoplasmal disease ash yellows (AshY) retards growth of Fraxinus (ash) spp. and causes or contributes to decline of the intolerant species $F$. americana (white ash; 2,12,14). AshY occurs in urban and rural landscapes and forests from the Rocky Mountain region eastward in North America $(5,14,21)$. This disease has not been identified on other continents. Phytoplasma strains associated with AshY are a genetically coherent group, provisionally classified and named as 'Candidatus Phytoplasma fraxini' (6). Strains of this taxon

Corresponding author: W. A. Sinclair E-mail: was1@cornell.edu

This research was supported by the United States Department of Agriculture McIntire-Stennis Cooperative Forestry Program, the Horticultural Research Institute, and the Iowa Nursery and Landscape Association Research Corporation.

Accepted for publication 8 March 2000.

Publication no. D-2000-0418-01R

(C) 2000 The American Phytopathological Society vary in aggressiveness (13) sensu Van der Plank (20).

Many cultivars of Fraxinus are recognized $(8,9)$, and several are used as shade trees in North America. Those most commonly planted within the known range of AshY are members of $F$. americana or $F$. pennsylvanica (green ash). The latter species is more tolerant of AshY phytoplasmal infection than is the former $(15,16)$. Heritable intraspecific variation in tolerance of AshY occurs in F. pennsylvanica (18) and is presumed to occur also in other ash species. However, the relative abilities of Fraxinus cultivars to tolerate infection by AshY phytoplasmas are unknown. In this article, "tolerance" refers to the ability of a plant to grow while colonized by phytoplasmas. Tolerance can be quantified by comparing growth of diseased and healthy plants.

The work reported here had three objectives: to characterize the relative levels of tolerance of 11 commercial ash cultivars to six AshY phytoplasma strains, to assess differences in aggressiveness of these strains under field conditions, and to detect possible cultivar-phytoplasma strain interactions. Such interactions would indicate differential virulence sensu Van der Plank (20) of phytoplasma strains.

\section{MATERIALS AND METHODS}

Experimental design and plant maintenance. Parallel experiments of randomized complete block design with five replications of four treatments were conducted in 1996 to 1999 at Ames, IA, and Ithaca, NY. The ash materials, provided by $\mathrm{J}$. Frank Schmidt and Son Co. (Boring, OR), consisted of dormant 1- or 2-year-old trees, 1 to $2 \mathrm{~m}$ tall, that had grown from buds grafted on green ash seedling rootstocks. Six cultivars of green ash (Bergeson, Dakota Centennial, Marshall, Patmore, Summit, and Urbanite) and five of white ash (Autumn Applause, Autumn Purple, Champaign County, Rosehill, and Skyline) were provided. Twenty trees of each of 10 cultivars (Urbanite omitted) at Ames and 11 cultivars at Ithaca were selected for similarity of stem diameters within cultivars. All trees were pruned to $1 \mathrm{~m}$ in height measured from the graft union, rootpruned, and planted in late April at Ames or early May at Ithaca in 25-liter pots in a mixture of 3 parts composted pine bark, 2 parts peat moss, and 1 part mushroom compost (Beautiful Land Products, Inc., West Branch, IA) at Ames or in a steamed mixture of 2 parts peat moss, 1 part sandy loam soil, and 1 part perlite at Ithaca. During the 1996 growing season, the trees at Ames were kept in a greenhouse, while trees at Ithaca were kept on a gravel pad outdoors and tended as if in a greenhouse. Trees at both locations were fertilized weekly with dilute soluble liquid fertilizer. Four trees of each cultivar were randomly assigned to each of five blocks and then were assigned to three phytoplasma strain treatments and the control within each block. Trees were allowed to grow 7 weeks before inoculation by grafting as described below, and then were allowed to complete their 1996 growth undisturbed.

Before the 1997 growing season, the trees were again pruned to a height of $1 \mathrm{~m}$ and all branches except the topmost two 
were removed from each tree. This procedure reduced the two remaining branches to upward-curving stubs approximately 20 $\mathrm{cm}$ long, ending $1 \mathrm{~m}$ above the graft union. Each stub had at least two nodes with large winter buds. This pruning standardized tree height and form before the onset of phytoplasma-related growth effects. The trees were then transplanted to field plots where the original randomized complete block arrangement was reproduced. The trees were allowed to grow for 3 years. Tree spacing was 1.0 by $5.5 \mathrm{~m}$ at Ames and 3.7 by $3.7 \mathrm{~m}$ at Ithaca.

Phytoplasma strains and treatments. Six phytoplasma strains, identified by polymerase chain reaction-restriction fragment length polymorphism (PCR-RFLP) analyses as members of the AshY group (6), were employed in these evaluations. A phytoplasma strain, as considered here, is a population derived from a single plant. Strains from Midwestern sources (AshY6 from St. Paul, MN; AshY7 from Ann Arbor, MI, and AshY11 from Ames, IA) were used at Ames, and strains from eastern sources (AshY4 from Verbank, NY; LWB1 from Ithaca, NY; and LWB3 from Boston, MA) were used at Ithaca. The $16 \mathrm{~S}$ rDNA sequence of each of these strains is archived in GenBank (6). Strains except AshY11 had been transferred by grafting from diseased Fraxinus spp. (AshY strains) or Syringa spp. (lilac; LWB strains) to $F$. velutina (velvet ash) and were maintained in potted plants of this species in a screened greenhouse. Insecticides were applied periodically to prevent unwanted introduction or transmission of phytoplasmas. Strain AshY11 was collected as leafy twig segments from a large witches'broom on green ash in Ames at the time of inoculation in 1996. It was then transferred by grafting to velvet ash and was later verified as an AshY phytoplasma and maintained as the other strains.

Each tree in the phytoplasma treatments was inoculated twice on the same day by cleft grafting two side branches with leafy stem segments 10 to $12 \mathrm{~cm}$ long or patch grafting the main stem with two bark patches of about 8 by $35 \mathrm{~mm}$, or by grafting one scion of each type from a tree infected with the appropriate phytoplasma strain. Grafts were wrapped with grafting tape, and cleft-grafted scions were enclosed in polyethylene bags for 4 weeks, when vascular connections were sufficient to sustain transpiration. Nearly all bark patches made union with recipient stems. In the Ithaca trial, 35 trees on which one or both cleft grafts failed were regrafted, 4 weeks after the initial grafting, with one or two bark patches from velvet ash plants containing appropriate phytoplasma strains. Fewer cleft grafts failed at Ames, and regrafting was not done there.

Scion donors for all strains except AshY11 were potted velvet ash trees that had been allowed to begin growth 4.5 months before the time of inoculation, so that all or most branches would be colonized by phytoplasmas when harvested for use as inoculum. This colonization was verified by DAPI (4',6-diamidino-2-phenylindole $2 \mathrm{HCl}$ ) fluorescence tests (10) on longitudinal sections of leaf rachises before plants were designated as inoculum sources. The scion donor for strain AshY11 was the same witches'-broom from which the strain was obtained.

Each control plant was treated as follows. Bark on the main stem about $30 \mathrm{~cm}$ above the soil line was opened to create a rectangular flap of about 8 by $20 \mathrm{~mm}$, hinged on one side. A piece of succulent tissue from a potted green ash of a clone known to be infected with a tobamovirus and a nepovirus was placed beneath the bark flap, which was then pressed shut firmly enough to partially crush the introduced tissue and adjacent inner phloem of the flap. The wound was then wrapped with grafting tape. Introduced tissue pieces were of two types which were used interchangeably: rectangular blocks of succulent innermost stem phloem ( 1 by 1 by 10 $\mathrm{mm}$ ) or $10-\mathrm{mm}$-long segments of thin succulent stems. The rationale for this treatment was that deliberate exposure of control plants to viruses by contaminating a wound similar to that made for a barkpatch graft would increase the similarity between controls and phytoplasma-inoculated plants with respect to possible cryptic viruses in scions and patches used as inoculum. Deliberate viral contamination of controls would minimize the likelihood of falsely attributing to phytoplasmas a growth suppression or foliar color change actually caused by viruses. Tobamoviruses and nepoviruses occur commonly in ash in New York State $(1,3,4)$ and were present in some of the ash materials in the greenhouse at Ithaca where phytoplasma strains were maintained. Viruses in the green ash clone used as a source of tissue pieces had been identified to genus level commercially (Agdia, Inc., Elkhart, IN) through an enzyme-linked immunosorbent assay (ELISA) test, and particles consistent with these diagnoses had been visualized by electron microscopy in expressed sap. Virus assays were not performed on scion donors or other experimental trees.

Observations, measurements, and analyses. The DAPI fluorescence test (10) was used to detect phytoplasmal infection as previously described $(14,17)$. One root, 1 to $3 \mathrm{~mm}$ in diameter, from every tree was tested in 1997 or 1998. Inoculated trees with negative test results were resampled and tested again. Control trees that displayed anomalous form or color or dramatically suppressed growth in 1998 or 1999 were also retested. A positive reaction in the DAPI test was accepted as evidence that a tree was infected with phytoplasmas.

Symptoms were recorded annually in late spring (for cankers, dieback, and ani- mal damage) and late summer (for foliar color and morphological abnormalities such as deliquescent branching, witches'brooms, and yellows sprouts). Yellows sprouts are dwarfed shoots with simple, usually chlorotic leaves, growing from the root collar region, that often develop into witches'-brooms (7). Foliar color of trees at Ames was scored in mid-August 1999 on a 1-to-4 scale where $1=$ severely chlorotic and $4=$ dark green. Foliar color of trees at Ithaca was measured in midAugust 1999 with a Minolta Chlorophyll Meter Model SPAD-502 (Spectrum Technologies Inc., Plainfield, IL). Values obtained with this instrument are positively correlated with chlorophyll content (11). An average value for each tree was calculated from at least five measurements on different leaves.

Analyses of tree growth were based on measurements of tree height and stem diameter at $20 \mathrm{~cm}$ above the graft union, recorded annually after growth was complete in 1996 to 1998 at Ames and 1996 to 1999 at Ithaca. The data were first integrated into a volume index (VI): (stem diameter in millimeters $)^{2} \times$ height in centimeters $\times 10^{-3}$. Tree growth over 2 years (at Ames) or 3 years (at Ithaca) was expressed as in the following example: Growth $_{96-99}=\left(\mathrm{VI}_{99}-\mathrm{VI}_{96}\right) / \mathrm{VI}_{96}$. In the term $\mathrm{VI}_{96}$, the height of every tree was 100 $\mathrm{cm}$. To facilitate comparisons among cultivars as affected by AshY, the growth and foliar color of each diseased (DAPI-positive) tree were expressed as proportions of the average growth and foliar color of the noninfected (DAPI-negative) trees of the same cultivar. This scheme standardized the differing growth rates and foliar colors of noninfected trees of the various cultivars. The resulting variables are termed "relative growth" and "relative greenness." Uninoculated controls and inoculated DAPI-negative trees of each cultivar were grouped for these calculations because their growth rates were similar and because fewer than five uninoculated controls of some cultivars remained in 1999.

Quantitative data were subjected to analyses of variance using a general linear model. Differences between treatment means were assessed by $t$ tests or least significant differences, and relationships of qualitative variables to treatments were assessed by contingency tests (19).

\section{RESULTS}

Phytoplasmal infection. Positive DAPI reaction in phloem sieve tubes was detected in 110 of 150 inoculated trees $(73 \%)$ in Iowa and in 143 of 165 inoculated trees $(87 \%)$ in New York. Frequency of infection was nearly equal in the two ash species at both locations. All controls in both locations were scored negative when first tested with DAPI. Controls that developed anomalous symptoms in 1998 or 1999 were retested but remained negative, ex- 
cept for one tree in New York that showed yellowing and stunting in 1998 and was scored positive in its second test. The incidence of infection in Iowa varied with phytoplasma strain from 33 to 41 trees out of 50 inoculated. Incidence in New York varied from 44 to 52 trees infected out of 55 inoculated per strain. These incidence values in each location were consistent with the hypothesis of no significant difference among strain treatments. For Iowa, $\chi^{2}$ with $2 \mathrm{df}=2.52, P<0.50$; for New York, $\chi^{2}$ with $2 \mathrm{df}=5.14, P<0.10$.

Symptoms. Incidence of witches'brooms or yellows sprouts (analyzed as one variable) was tallied annually. The proportion of DAPI-positive trees that displayed one of these symptoms in one or more years was $43 \%$ in Iowa and $44 \%$ in New York (Fig. 1). In addition, three inoculated DAPI-negative trees were scored as having brooms in Iowa, while no DAPInegative trees had brooms in New York. Variation between ash species in incidence of witches'-brooms was significant in Iowa but not in New York (Table 1). Incidence of brooms or yellows sprouts also varied significantly among phytoplasma strain treatments, with strains AshY6 and LWB1 inducing brooms most frequently in Iowa and New York, respectively (Table 1). In both Iowa and New York, phytoplasmainfected trees that produced witches'brooms grew significantly less $(P<0.05)$ than infected trees that did not produce brooms (data not shown).

Frequency of deliquescent branching was more than five times greater in infected than in noninfected trees in Iowa and more than four times greater in infected than in noninfected trees in New York (Fig. 1). In New York, winter damage in 1997 to 1998 led to bark colonization by opportunistic fungi that caused cankers on many mainstems. Canker incidence was approximately $30 \%$ in both DAPI-positive and DAPI-negative trees.

Cumulative incidence of severe dieback (usually to ground level) or death in the Iowa planting in 1997 to 1999 was $10 \%$ and was not significantly related to phytoplasmal infection. In the New York planting, however, incidence of severe dieback or death was $24 \%$, and the frequency of this damage was significantly greater in phytoplasma-infected than in noninfected trees (28 and 16\%, respectively; Fig. 1). The cultivar Urbanite, tested only in New York, was uniquely affected, inasmuch as all inoculated trees and one of the controls

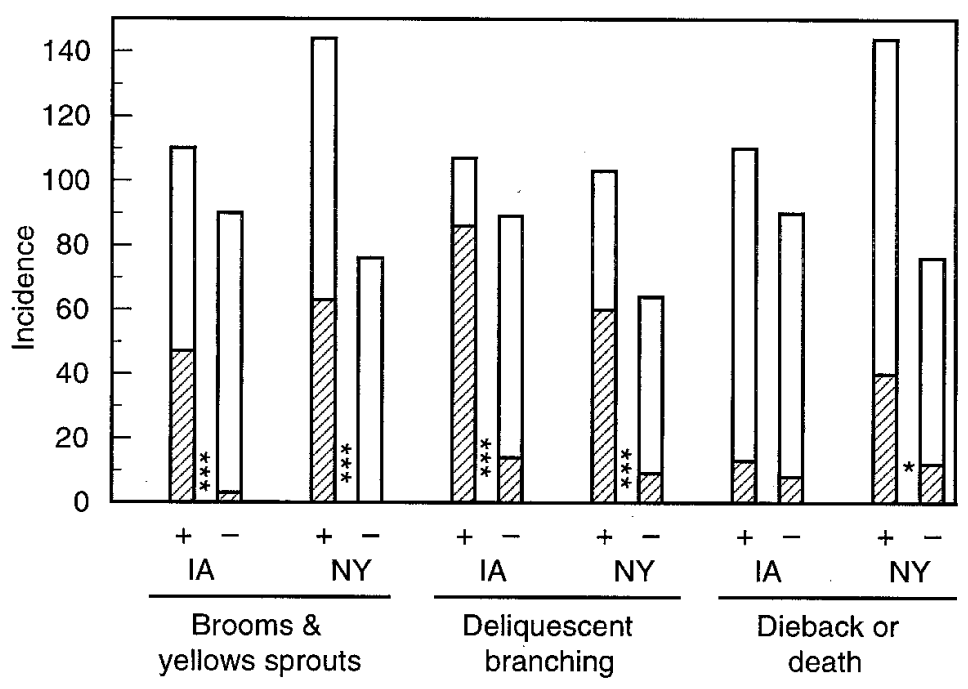

Fig. 1. Incidence of morphological symptoms as related to phytoplasmal infection (+ or -$)$ at test sites in Iowa (IA) and New York (NY). Trees scored positive in the DAPI test were considered to be infected. Each bar shows number of trees with symptoms (hatched portion) among all trees with the indicated DAPI test result. Only trees alive in 1999 were scored for deliquescent branching. Single and triple asterisks indicate $P<0.05$ and $P<0.001$, respectively, of $\chi^{2}$ values associated with differences in incidence between infected and noninfected trees.

Table 1. Incidence of witches'-brooms or yellows sprouts on trees infected with phytoplasmas as related to tree species and phytoplasma strain, with contingency tests of differences between species and among strains

\begin{tabular}{|c|c|c|c|c|}
\hline \multirow{3}{*}{$\begin{array}{l}\text { Species } \\
\text { Incidence } \\
\chi^{2}, P\end{array}$} & \multicolumn{2}{|c|}{ Iowa } & \multicolumn{2}{|c|}{ New York } \\
\hline & $\begin{array}{c}\text { Green ash } \\
31\end{array}$ & $\begin{array}{c}\text { White ash } \\
54\end{array}$ & $\begin{array}{c}\text { Green ash } \\
38\end{array}$ & $\begin{array}{c}\text { White ash } \\
51\end{array}$ \\
\hline & \multicolumn{2}{|c|}{$5.48,<0.025$} & \multicolumn{2}{|c|}{$2.37,>0.10$} \\
\hline $\begin{array}{l}\text { Phytoplasma strain } \\
\text { Incidence } \\
\chi^{2}, P\end{array}$ & $\begin{array}{c}\text { AshY6 } \\
58\end{array}$ & $\begin{array}{c}\text { AshY11 } \\
52\end{array}$ & $\begin{array}{c}\text { AshY4 } \\
32\end{array}$ & $\begin{array}{c}\text { LWB3 } \\
36\end{array}$ \\
\hline
\end{tabular}

${ }^{a}$ Percent trees with witches'-brooms or yellows sprouts among trees with positive DAPI test scores. died to ground level. This cultivar was not considered in analyses of growth or foliar color.

Growth and relative growth. Trees of all cultivars grew more rapidly in Iowa than in New York, but growth rates of noninoculated controls of the various cultivars at the two locations were not significantly correlated ( $r=-0.22$; Fig. 2$)$. Variance in growth at each location was influenced most strongly by phytoplasmal infection (Table 2, Fig. 3) and less strongly, although still significantly, by ash species and cultivars (Table 2). Block variation in growth was significant in New York (Table 2), reflecting varying soil drainage in the planting site and more severe damage by deer in some blocks than in others.

Phytoplasma strains were the greatest source of variance in relative growth (response to infection) in Iowa, while both strains and ash species were significant sources of variance in New York (Table 3, Fig. 4). In Iowa, strain AshY11 caused the greatest growth suppression and AshY7 the least. In New York, strain LWB1 caused the greatest growth suppression and AshY4 the least.

On average, diseased trees in Iowa and New York grew 49 and 59\% as rapidly, respectively, as the noninfected tree groups (Fig. 5). Cultivars varied significantly in relative growth at each location, but no cultivar exhibited high tolerance of infection (i.e., only slight growth suppression) at both locations (Fig. 5). Strain-cultivar interactions in relative growth were not significant at either location (data not

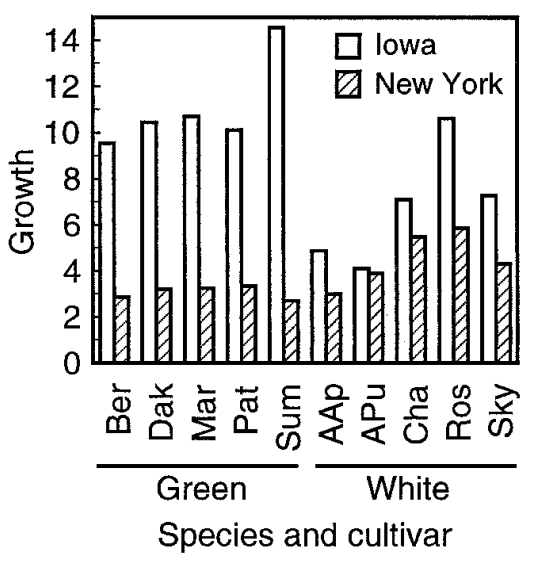

Fig. 2. Growth of noninoculated control trees of five green ash and five white ash cultivars at Ames, IA, and Ithaca, NY. Growth = increase in volume index (VI) over 2 years (Iowa) or 3 years $($ New York)/initial VI. VI $=($ stem diameter in millimeters $)^{2} \times$ height in centimeters $\times$ $10^{-3}$. Differences between species and among cultivars were both significant at $P<0.001$ in Iowa and were significant at $P=0.002$ and $P=$ 0.026 , respectively, in New York. Cultivars are (abbreviations underlined): Bergeson, Dakota Centennial, Marshall Seedless, Patmore, Summit, Autumn Applause, Autumn Purple, Champaign County, Rosehill, and Skyline. 
shown). The relative growth rates of green ash cvs. Bergeson, Dakota Centennial, and Patmore and white ash cv. Autumn Applause were at or above average at both locations (Fig. 5). For these determinations, average was considered to be the range within one standard error of the grand mean at each location. White ash cvs. Champaign County and Rosehill showed marked disease-associated growth suppression at both locations (Fig. 5). The correlation between cultivar means for relative growth in Iowa and New York was not significant $(r=0.41, P>0.10)$.

Foliar color and relative greenness. Foliar color was influenced strongly by phytoplasmal infection and ash cultivar at both locations and by planting site variation (block effect) in New York (Table 2, Fig. 3). Relative greenness (color response to infection) was influenced strongly by phytoplasma strain in Iowa and by ash species in New York (Table 3, Fig. 4). In New York, phytoplasma-associated color loss was more severe in white ash than in green ash. Variation in cultivar response was significant in both locations (Fig. 5). Strain-cultivar interactions were not significant at either location (data not shown). Green ash cvs. Bergeson and Patmore and white ash cvs. Autumn Applause and Autumn Purple had relative greenness at or above the average for all clones (as defined above) at each location. Relative greenness was positively and significantly correlated with relative growth at each location $(r=$ 0.50 in Iowa and 0.55 in New York, $P<$ 0.01). Cultivar means for relative greenness in Iowa and New York were not correlated, however $(r=0.09)$.

As a test of the influence of phytoplasmal infection versus possible viral infection (initiated during graft-inoculation) on foliar color, the color scores (Iowa) and measured values for greenness (New York) of phytoplasma-inoculated, DAPI-positive trees were compared to the corresponding values for phytoplasma-inoculated, DAPInegative trees and were found to be significantly different $(P<0.001)$ in both locations (data not shown). Therefore, most of the color loss in inoculated trees could be attributed to phytoplasmas.

Cultivars at each location were ranked from least to greatest in growth loss and separately in color loss due to infection, and rank correlation coefficients for the two variables were calculated. These values were $0.62, P<0.10$ in Iowa and $0.78, P<$ 0.05 in New York. Cultivar ranks in Iowa

Table 2. Influences of five factors on variation in ash growth rates and foliar color ${ }^{\mathrm{a}}$

\begin{tabular}{|c|c|c|c|c|}
\hline \multirow[b]{2}{*}{ Factor } & \multicolumn{2}{|c|}{ Iowa } & \multicolumn{2}{|c|}{ New York } \\
\hline & $\boldsymbol{F}$ & $\boldsymbol{P}$ & $\boldsymbol{F}$ & $\boldsymbol{P}$ \\
\hline \multicolumn{5}{|l|}{ Growth } \\
\hline Inoculation treatment & 25.18 & $<0.001$ & 11.42 & $<0.001$ \\
\hline DAPI test result & 94.95 & $<0.001$ & 43.64 & $<0.001$ \\
\hline Species & 35.59 & $<0.001$ & 6.19 & 0.014 \\
\hline Cultivar & 5.45 & $<0.001$ & 2.38 & 0.015 \\
\hline Block & 0.57 & 0.68 & 4.41 & 0.002 \\
\hline \multicolumn{5}{|l|}{ Foliar greenness } \\
\hline Inoculation treatment & 46.76 & $<0.001$ & 12.90 & $<0.001$ \\
\hline DAPI test result & 125.01 & $<0.001$ & 51.78 & $<0.001$ \\
\hline Species & 0.69 & 0.41 & 0.27 & 0.60 \\
\hline Cultivar & 2.73 & 0.005 & 3.19 & 0.001 \\
\hline Block & 0.11 & 0.98 & 2.95 & 0.022 \\
\hline
\end{tabular}

a Influences are displayed as $F$ values and associated probabilities obtained in one-way analyses of variance with 199 and 194 total df for growth and color, respectively, in Iowa; and 168 and 163 total df for growth and color, respectively, in New York.

were not significantly correlated with ranks in New York $(r=0.26$ and $r=0.18$ for growth and color, respectively).

\section{DISCUSSION}

Ash cultivars at each location varied significantly in growth of noninoculated
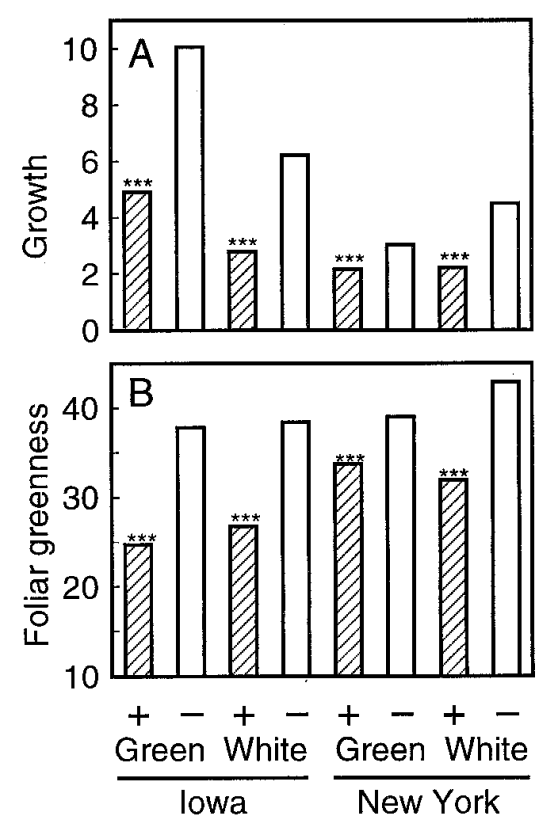

Fig. 3. (A) Growth and (B) foliar greenness of green ash and white ash in Iowa and New York as related to phytoplasmal infection (positive or negative DAPI test result). Growth = increase in volume index (VI) over 2 years (Iowa) or 3 years $($ New York $) /$ initial VI. VI $=$ (stem diameter in millimeters $)^{2} \times$ height in centimeters $\times 10^{-3}$. Foliar greenness in the New York planting was measured in August 1999 with a Minolta SPAD-502 Chlorophyll Meter. Foliar color in the Iowa planting was scored in August 1999 on a 1-to-4 scale where $1=$ severely chlorotic and $4=$ dark green, and mean color scores were multiplied by 10 to obtain values similar in magnitude to those obtained with the chlorophyll meter. Triple asterisks indicate $P<0.001$ of the $t$ value associated with difference between + and averages within each species in each location.

Table 3. Analyses of variance in growth and foliar greenness of phytoplasma-infected ash relative to growth and foliar greenness of noninfected trees of the same cultivars ${ }^{\mathrm{a}}$

\begin{tabular}{|c|c|c|c|c|c|c|c|c|}
\hline \multirow[b]{2}{*}{ Source } & \multicolumn{4}{|c|}{ Iowa } & \multicolumn{4}{|c|}{ New York } \\
\hline & DF & MS & $\boldsymbol{F}$ & $\boldsymbol{P}$ & DF & MS & $\boldsymbol{F}$ & $P$ \\
\hline \multicolumn{9}{|l|}{ Relative growth } \\
\hline Phytoplasma strain & 2 & 2.134 & 27.46 & $<0.001$ & 2 & 0.361 & 4.90 & 0.009 \\
\hline Ash species & 1 & 0.045 & 0.57 & 0.45 & 1 & 1.210 & 16.37 & $<0.001$ \\
\hline Block & 4 & 0.084 & 1.08 & 0.37 & 4 & 0.299 & 4.05 & 0.004 \\
\hline Error & 102 & 0.078 & $\ldots$ & $\ldots$ & 97 & 0.074 & $\ldots$ & $\ldots$ \\
\hline \multicolumn{9}{|l|}{ Relative greenness } \\
\hline Phytoplasma strain & 2 & 1.176 & 37.35 & $<0.001$ & 2 & 0.052 & 1.88 & 0.158 \\
\hline Ash species & 1 & 0.107 & 3.40 & 0.068 & 1 & 0.174 & 6.35 & 0.013 \\
\hline Block & 4 & 0.050 & 1.58 & 0.186 & 4 & 0.067 & 2.46 & 0.051 \\
\hline Error & 98 & 0.031 & $\ldots$ & $\ldots$ & 95 & 0.027 & $\ldots$ & $\ldots$ \\
\hline
\end{tabular}

${ }^{a}$ Relative growth of each phytoplasma-infected tree $=$ growth (defined below)/average growth of noninfected trees of the same cultivar. Growth $=$ increase in volume index (VI) over 2 years (Iowa) or 3 years (New York)/initial VI. VI $=(\text { stem diameter in millimeters })^{2} \times$ height in centimeters $\times 10^{-3}$. Dead trees and those with dieback to near ground level were excluded. The cultivar Urbanite was excluded, because 16 of its 20 trees died or had severe dieback. Block-cultivar and block-strain interactions were nonsignifcant and are incorporated into the error terms of the analyses. 
trees and in severity of growth depression and color loss induced by phytoplasmal infection, but cultivar means for these variables were not significantly correlated between locations. Although green ash cultivars as a group were more tolerant (sustained less growth and color depression) than white ash cultivars in New York, significant interspecific differences in these variables did not occur in Iowa. These disparities may be interpreted in three ways. Most likely, climate, site, and soil differences between the Iowa and New York plantings caused major differences in growth and disease response of some clones. These site-related differences in clonal performance may have been accentuated by winter damage in two successive years in New York, which led to cankers, bud mortality, and suppressed growth throughout the planting. Noninoculated control trees in New York did not begin to grow rapidly until 1999. An alternative interpretation is that, despite evidence to the contrary, the null hypothesis of no difference in tolerance among cultivars is correct. If this were true, however, one would not expect an array of only 10 cultivars to be a significant source of variance in disease response at each of two locations. The third possibility is that straincultivar interactions account for differences in clonal performance between Iowa and New York. This possibility cannot be critically evaluated because different phytoplasma strains were used at the two locations. Strain-cultivar interactions were not significant within locations.

Given the low correlation of cultivar performance in Iowa to that in New York, the cultivars cannot be ranked credibly for tolerance of AshY phytoplasmal infection. On the other hand, given that cultivar performance did vary significantly at each location, one may note cultivars that were among those least affected at both locations: Autumn Applause, Bergeson, Patmore, and Dakota Centennial with respect to relative growth; and the first three of these with respect to foliar greenness. By similar reasoning, the severe growth depression of AshY-affected Champaign County and Rosehill at both locations may be noted. The mortality of Urbanite in New York set this cultivar apart from all others tested.

Incidence of morphologic symptoms of AshY varied with tree species and phytoplasma strain. Witches'-brooms or yellows sprouts developed on fewer than half of the infected trees and were more frequent on white ash than on green ash in both locations. These observations were in accord with accounts of AshY symptomology and with the reputed lower tolerance of white ash than green ash $(14,16)$. The three DAPI-negative trees that were scored as having brooms in Iowa may have been infected with phytoplasmas (false negative in the DAPI test) or may have produced basal sprouts that were erroneously tallied as yellows sprouts. Brooms and yellows sprouts were tallied as one variable because these growth forms are developmental variations of the same phenomenon: release of dormant or adventitious buds in response to infection (7). The more common occurrence of deliquescent branches on infected than on noninfected (by DAPI test) trees was in accord with a previous interpretation that deliquescent branching is indicative of, but not diagnostic for, phytoplasmal infection in ash (14). Dieback or mortality of trees occurred mainly during the dormant season and, in New York, was significantly more common in trees harboring phytoplasmas than in other trees. This finding is consistent with previous observations of frost-induced basal cankers and bark cracks in white ash affected by phytoplasmas (7).

Phytoplasma strains at each location were significant sources of variation in relative growth and, in Iowa, relative greenness of foliage. In Iowa, strains AshY6 and AshY11 caused more severe
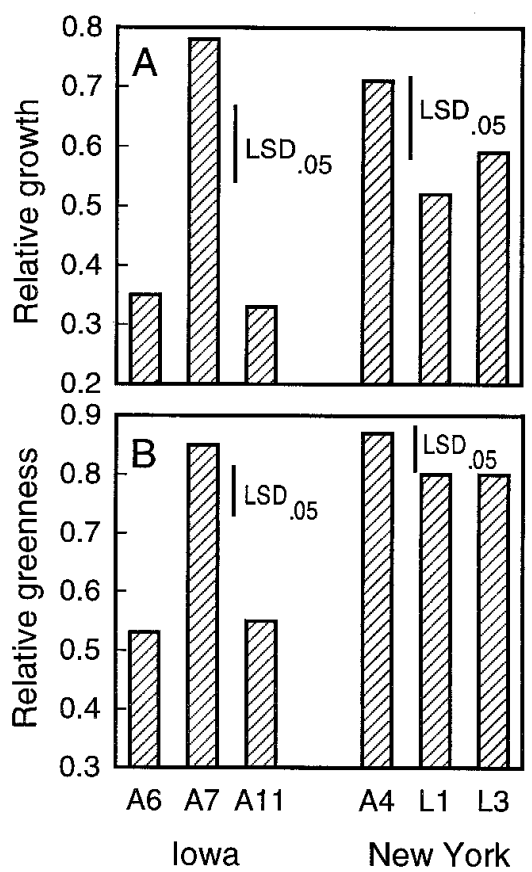

Fig. 4. (A) Average relative growth and (B) relative greenness of 10 ash cultivars as affected by three strains of ash yellows (AshY) phytoplasmas in Iowa and three strains in New York. Growth = increase in volume index (VI) over 2 years (in Iowa) or 3 years (in New York $) /$ initial VI. VI $=$ (stem diameter in millimeters $)^{2} \times$ height in centimeters $\times 10^{-3}$. Relative growth of each tree $=$ growth as a proportion of the average growth of noninfected trees of the same cultivar. Relative greenness of each tree $=$ color score (in Iowa) or measured value (in New York) as a proportion of the average score or measured value of noninfected controls of the same cultivar. Strain designations: A4, A6, A7, A11, L1, and L3 = AshY4, AshY6, AshY7, AshY11, LWB1, and LWB3, respectively. $\mathrm{LSD}=$ least significant difference. symptoms than did AshY7. In New York, strains LWB1 and LWB3 caused more severe symptoms than did AshY4. The frequency of witches'-brooms also varied with phytoplasma strains; those causing greatest suppression of growth and color also induced witches'-brooms most frequently. These strain-associated differences
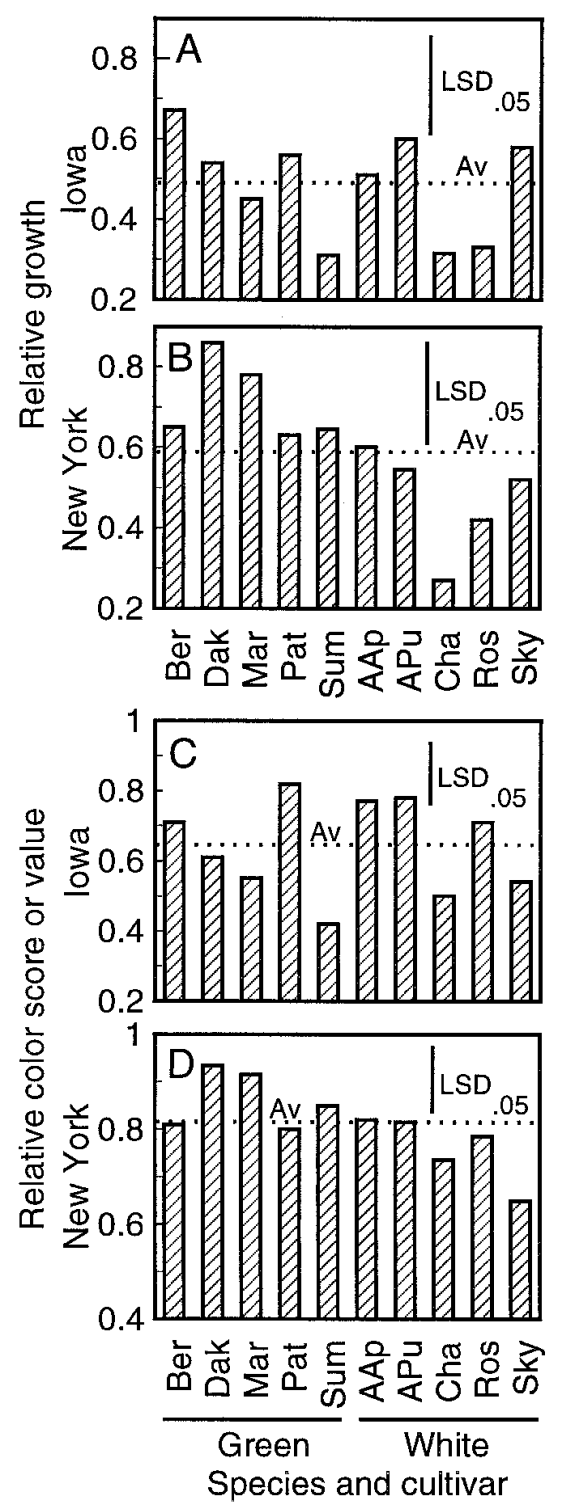

Fig. 5. (A, B) Relative growth and (C, D) relative greenness of green ash and white ash cultivars infected with ash yellows phytoplasmas in Iowa and New York. Relative growth of each tree $=$ growth as a proportion of the average growth of noninfected trees of the same cultivar. Relative greenness of each tree $=$ color score (in Iowa) or measured value (in New York) as a proportion of the average score or measured value of noninfected controls of the same cultivar. Cultivar designations (abbreviations underlined): Bergeson, Dakota Centennial, Marshall Seedless, Patmore, Summit, Autumn Applause, Autumn Purple, Champaign County, Rosehill, and Skyline. Unweighted averages (Av) of relative growth and relative greenness of all cultivars at each location are shown. LSD = least significant difference. 
at each location were in accord with previously detected differences in aggressiveness of the strains in greenhouse assays (13). The inverse relationship between growth rate and formation of witches'brooms on phytoplasma-infected trees was expected based on previous observations of naturally diseased trees (7).

Cultivar-strain interactions were not detected. Such interactions would indicate differential virulence sensu Van der Plank (20) of phytoplasma strains or differential tolerance of host genotypes to the various members of an array of strains. Such interactions between host and pathogen genotypes have not yet been reported for any phytoplasmal pathosystem.

The ash clones in these experiments were all on seedling green ash rootstocks. These rootstocks may have lessened the severity of disease impact on white ash cultivars and thus narrowed the apparent interspecific difference in disease severity. This supposition is based on prior findings that tolerant rootstocks lessen the growth impact of AshY phytoplasmas on scions (16) and that green ash is more tolerant than white ash of phytoplasmal infection $(15,16)$.

AshY occurs in urban shade trees as well as wild trees and apparently depresses growth in both situations $(5,15)$. AshYassociated chlorosis is also documented from field studies (18 and this article). Some strains of the pathogen cause severe symptoms in assays performed with young plants (13 and this article). Up to now, however, AshY has not been considered a significant health problem in urban ash populations. If the disease becomes problematic, as could occur due to spread of aggressive strains of the pathogen, the results here reported may serve as a basis for choosing cultivars least likely to be severely affected.

\section{ACKNOWLEDGMENTS}

We thank the J. Frank Schmidt and Son Co., Boring OR, for providing the ash cultivars; S. Parker for logistical help; W. Graves for planning advice; A. Aiello, D. Cantonwine, M. Healy, S. Wright, C. Helmsley, and G. Hill for assistance with graft-inoculations and technical help; and an anonymous reviewer for helpful comments about the manuscript.

\section{LITERATURE CITED}

1. Castello, J. D., Amico, L. A., and O'Shea, M. T. 1984. Detection of tobacco mosaic and tobacco ringspot viruses in white ash trees by enzyme-linked immunosorbent assay. Plant Dis. 68:787-790.

2. Dyer, A. T., and Sinclair, W. A. 1991. Root necrosis and histological changes in surviving roots of white ash infected with mycoplasmalike organisms. Plant Dis. 75:814-819.

3. Ferris, M. A., and Castello, J. D. 1988. Detection of tomato ringspot virus in white ash and adjacent vegetation in central New York. Can. J. For. Res. 18:813-817.

4. Ferris, M. A., Castello, J. D., and Sinclair, W. A. 1989. Effects of virus and mycoplasmalike organism infection on green and white ash. Phytopathology 79:579-583.

5. Gleason, M. L., Parker, S. K., Engle, T. E., Flynn, P. H., Griffiths, H. M., Vitosh, M. A., and Iles, J. K. 1997. Ash yellows occurrence and association with slow growth of green ash in Iowa and Wisconsin cities. J. Arboric. 23:77-82.

6. Griffiths, H. M., Sinclair, W. A., Smart, C. D., and Davis, R. E. 1999. The phytoplasma associated with ash yellows and lilac witches'broom: 'Candidatus Phytoplasma fraxini.' Int. J. Syst. Bacteriol. 49:1605-1614.

7. Matteoni, J. A., and Sinclair, W. A. 1985. Role of the mycoplasmal disease, ash yellows, in decline of white ash in New York State. Phytopathology 75:355-360.

8. McArdle, A. J., and Santamour, F. S., Jr. 1984. Checklists of cultivars of European ash (Fraxinus) species. J. Arboric. 10:21-32.

9. Santamour, F. S., Jr., and McArdle, A. J. 1983. Checklist of cultivars of North American ash (Fraxinus) species. J. Arboric. 9:271276.

10. Seemüller, E. 1976. Investigations to demon- strate mycoplasmalike organisms in diseased plants by fluorescence microscopy. Acta Hortic. 67:109-112.

11. Sibley, J. L., Eakes, D. J., Gilliam, C. H., Keever, G. J., Dozier, W. A., Jr., and Himelrick, D. G. 1996. Foliar SPAD-502 meter values, nitrogen levels, and extractable chlorophyll for red maple selections. HortScience 31:468-470.

12. Sinclair, W. A., and Griffiths, H. M. 1994. Ash yellows and its relationship to dieback and decline of ash. Annu. Rev. Phytopathol. 32:49-60.

13. Sinclair, W. A., and Griffiths, H. M. 2000 Variation in aggressiveness of ash yellows phytoplasmas. Plant Dis. 84:282-288.

14. Sinclair, W. A., Griffiths, H. M., and Davis, R. E. 1996. Ash yellows and lilac witches'broom: phytoplasmal diseases of concern in forestry and horticulture. Plant Dis. 80:468475.

15. Sinclair, W. A., Griffiths, H. M., and Treshow, M. 1993. Impact of ash yellows mycoplasmalike organisms on radial growth of naturally infected white, green, and velvet ash. Can. J. For. Res. 23:2467-2472.

16. Sinclair, W. A., Griffiths, H. M., and Whitlow, T. H. 1997. Comparisons of tolerance of ash yellows phytoplasmas in Fraxinus species and rootstock-scion combinations. Plant Dis. 81:395-398.

17. Sinclair, W. A., Iuli, R. J., Dyer, A. T., and Larsen, A. O. 1989. Sampling and histological procedures for diagnosis of ash yellows. Plant Dis. 73:432-435.

18. Sinclair, W. A., Whitlow, T. H., and Griffiths, H. M. 1997. Heritable tolerance of ash yellows phytoplasmas in green ash. Can. J. For. Res. 27:1928-1935.

19. Snedecor, G. W., and Cochran, W. G. 1989. Statistical Methods. 8th ed. Iowa State University Press, Ames.

20. Van der Plank, J. E. 1968. Disease Resistance in Plants. Academic Press, New York.

21. Walla, J. A., Jacobi, W. R., Tisserat, N. A., Harrell, M. O., Ball, J. J., Neill, G. B., Reynard, D. A., Guo, Y. H., and Spiegel, L. 2000. Condition of green ash, incidence of ash yellows phytoplasmas, and their association in the Great Plains and Rocky Mountain regions of North America. Plant Dis. 84:268274. 